\title{
The Effect of Guided Inquiry Model Assisted by Animation Video on Students' Concept Mastering of Wave Materials
}

\author{
*Arin Wildani, Agus Budiyono, Milisa Triastutik, Junaidi \\ Program Studi Pendidikan Fisika, Fakultas Keguruan dan Ilmu Pendidikan Universitas Islam \\ Madura. Jl. PP. Miftahul Ulum Bettet Pamekasan. Postal code: 69317 \\ *Corresponding Author e-mail: arinwildani@gmail.com
}

Received: July 2021; Revised: September 2021; Published: December 2021

\begin{abstract}
This study aims to determine the effect of guided inquiry model assisted by animated videos on students' mastery of physics concepts. This research is an experimental research. The method used in this study is a quasiexperimental with pretest posttest control group design. The population in this study were all students of class VII SMPI Terpadu Miftahul Ulum Tambelangan. The sample in this study is class VIII A as the experimental class and class VIIID as the control class, each class consists of 32 students. Determination of the sample using simple random sampling technique. The instrument in this study is a concept mastery test with 10 questions on wave material, which have been declared valid and reliable. Data analysis was done by test with $\mathrm{N}$-Gain test. Based on the results of the t-test analysis, the results of t-count (7.932) > t-table (1.98), and based on the $\mathrm{N}$-gain test obtained a value of 0.85 where the increase is included in the high category. From these results it can be concluded that the learning process with the guided inquiry model assisted by animated videos has a significant effect on students' mastery of concepts.
\end{abstract}

Keywords: guided inquiry, animated videos, mastery of concepts

How to Cite: Wildani, A., Budiyono, A., Triastutik, M., \& Junaidi, J. (2021). The Effect of Guided Inquiry Model Assisted by Animation Video on Students' Concept Mastering of Wave Materials. Prisma Sains : Jurnal Pengkajian Ilmu dan Pembelajaran Matematika dan IPA IKIP Mataram, 9(2), 193-198. doi:https://doi.org/10.33394/j-ps.v9i2.4065

https://doi.org/10.33394/j-ps.v9i2.4065

Copyright $\odot$ 2021, Wildani et al This is an open-access article under the CC-BY License.

\section{INTRODUCTION}

Physics or science is a branch of natural science that requires students to be able to understand the laws, concepts and principles that have been tested by previous scientists through various experiments (Indrajit, 2009). Physics is also one of the most important sciences and we always encounter it in everyday life (Lia, 2018). In accordance with their intellectual level, students are also expected to be able to assemble and compose the principles and concepts that have been previously mastered in their own language. Mastery of concepts is not only simple understanding but also able to describe the concepts that have been taught as a form of ability to understand, understand, apply and conclude objects (Kusairi, 2013). For most students, understanding the concept of physics is not easy because physics is a difficult subject and there are several concepts in physics that include abstract concepts so that students find it difficult to digest the material being studied (Budiyono, Hair, Wildani, \& Firdausiyah, 2020).

Submission of abstract physics concepts is sometimes not enough with just direct delivery because students will find it increasingly difficult to understand the concepts. Educators need to innovate learning to convey these abstract concepts. One of the innovations that can be done is the use of learning media in the learning process. One of the media that can be used is the use of computer technology (Gunawan, Harjono, \& Sutrio, 2017). These 
abstract physics concepts can be visualized in an easy-to-learn computer program in the form of images, video animations or graphics.

The use of video, image or graphic media has a very high appeal for students because the senses of sight and hearing are stimulated during the learning process. Learning physics becomes more interesting when using animated video media, making it easier for students to understand and master physics concepts (Yulianci, Gunawan, \& Doyan, 2017). Physics concepts that were originally abstract are no longer abstract because they can be seen in the form of videos, students are no longer just imagining but are already able to see and learn according to what is being seen.

The use of learning media in the learning process needs to be accompanied by the right learning model (Rahim, 2020). A learning model that is not only lectures and discussions but a learning model that makes students active in every aspect of learning as well as guided inquiry learning models. The guided inquiry learning model is a learning model that places students as learning subjects, which means that students are asked to understand the concept independently and the teacher monitors student activities while providing guidance on the student learning process. The guided inquiry model gives students the freedom to carry out learning that is appropriate and desired by students (Kusdiastuti, Harjono, Sahidu, \& Gunawan, 2017). The lack of freedom given to students in the learning process causes a low level of mastery of students' concepts (Gunawan, Harjono, \& Imran, 2016). Based on the results of previous research (Hafsyah, Prihandono, \& Yushardi, 2021; Kurniawati \& Diantoro, 2014; Umami \& Jatmiko, 2013; Wijayanti \& Hindarto, 2010) Guided inquiry learning model is able to increase mastery of concepts that will have an impact on learning outcomes.

One of the physical materials whose submaterial is abstract, among others, is waves. Submission of wave material directly without using media assistance will make students only imagine the material and will have an impact on students' lack of understanding of the concept of waves. To overcome this problem, this study applied collaborative use of learning models with learning media. The use of guided inquiry learning models assisted by animated video media has never been applied before to physics subjects, especially wave material. So, in this article, we will discuss the effect of applying a guided inquiry model assisted by animated videos on students' mastery of concepts in wave material.

\section{METHOD}

The type of research used in this study is experimental research. This research method is a quasi-experimental method using a pretest-posttest control group design. The population in this study were all students of class VIII SMPI Terpadu Miftahul Ulum Tambelangan. The sample consisted of two classes, namely class VIIIA as the experimental class and VIIID as the control class with 32 students in each class. Determination of the sample is done by using random sampling method. The experimental class carried out the learning process using animated video media with a guided inquiry learning model while the control class carried out the learning process using a guided inquiry learning model without animated video media.

Table 1. Summary of Results from Validity Test

\begin{tabular}{cccc}
\hline Test number & r-count & Test number & r-count \\
\hline 1 & 0,624648 & 8 & 0,580275 \\
2 & 0,661154 & 9 & 0,732296 \\
3 & 0,585349 & 10 & 0,539091 \\
4 & 0,756363 & 11 & 0,549316 \\
5 & 0,617615 & 12 & 0,677201 \\
6 & 0,713238 & 13 & 0,688251 \\
7 & 0,597673 & & \\
\hline
\end{tabular}


The concept mastery data used in this study were obtained before and after the treatment. The pre-treatment test aims to determine the initial level of students' conceptual knowledge and is given after treatment to determine the effect of animated video media on increasing students' conceptual mastery. The instrument in this study was a multiple choice question with 10 questions with five answer choices. The material used in the problem is waves. Validity and reliability tests were applied to the question instrument to test whether the instrument used was valid and reliable. The validity test was carried out using the product moment correlation and obtained results such as in Table 1 . The questions are declared valid with r-count > r-table, where the value of r-table with a sample of 32 students is 0.361 , meaning that if $r$-count $>0.361$ then the item is declared valid, whereas if $r$-count $<0.361$ then the item is declared invalid. Based on the results in Table 1, there are 13 questions that are declared valid. Furthermore, the reliability test was carried out on 13 questions which were declared valid. The reliability test was carried out using the alpha formula. Based on the reliability test with the alpha formula, 10 reliable questions were obtained with a reliability value of 0.82288 .

Data analysis was carried out by testing the hypothesis using the independent sample ttest using the SPSS version 16.00 program. Previously, the data was tested for normality using Shapiro Wilk and homogeneity test using Levene's test. In addition to testing the hypothesis, an N-gain score test was also carried out which was calculated using the MS Excel program to determine the increase in the concept understanding score with the interpretation of the $\mathrm{N}$-gain score as shown in Table 2.

Table 2. N-gain Score Interpretation

\begin{tabular}{cc}
\hline $\mathbf{N}$-gain Score & Category \\
\hline $\mathrm{N}$-gain $>0,70$ & High \\
$0,70>\mathrm{N}$-gain $\geq 0,30$ & Moderate \\
$\mathrm{N}$-gain $<0,30$ & Low \\
\hline
\end{tabular}

(Hake, 1999)

\section{RESULTS AND DISCUSSION}

The description of the students' physics concept mastery data based on the results of the pretest and posttest as shown in Table 3. The average value of the pretest mastery of students' concept mastery in the experimental class is 38.37 and the control class is 32.18 , while the posttest average value of students' concept mastery in the experimental class obtained for 89.93 and posttest for the control class of 79.12. The results of the normality test for the control class and the experimental class showed that the pretest and posttest data were normally distributed, with a significance value $>0.05$ as presented in Table 4 . Likewise for the homogeneity test results which showed homogeneous data variants, with a significance value $>0.05$. as shown in Table 5. With the fulfillment of these two conditions, hypothesis testing is then carried out, and the results obtained are $t$-count $>t$-table, with $t$-count $=7.932$ and t-table $=1.98$ (see Table 6). From these results it is known that there is a significant difference between students' mastery of physics concepts in the experimental class and the control class.

Table 3. The Data Description

\begin{tabular}{llllll}
\hline & N & Min & Max & Mean & Std. Deviation \\
\hline Pre-Kon & 32 & 30 & 50 & 38.38 & 5.31 \\
Pos-Kon & 32 & 70 & 90 & 79.13 & 5.01 \\
Pre-Eks & 32 & 20 & 40 & 32.19 & 5.40 \\
Pos-Eks & 32 & 80 & 98 & 89.94 & 5.19 \\
Valid N (listwise) & 32 & & & & \\
\hline
\end{tabular}


Table 4. Summary of Normality Test Results

\begin{tabular}{clcc}
\hline No. & \multicolumn{1}{c}{ Group } & Sig. & Conclusion \\
\hline 1 & Pretest for experimental class & 0,149 & Normal \\
2 & Posttest for experimental class & 0,200 & Normal \\
3 & Pretest for control class & 0,200 & Normal \\
4 & Posttest for control class & 0,108 & Normal \\
\hline
\end{tabular}

Table 5. Homogeneity Test Summary

\begin{tabular}{ccc}
\hline Test & Sig & Conclusion \\
\hline Pretest & 0,869 & Homogeneous \\
Posttest & 0,569 & Homogeneous \\
\hline
\end{tabular}

Table 6. Hypothesis Test Results (t-test for Equality of Means)

\begin{tabular}{llccccccc}
\hline & T & df & $\begin{array}{c}\text { Sig. (2- } \\
\text { tailed) }\end{array}$ & $\begin{array}{c}\text { Mean } \\
\text { Diff. }\end{array}$ & \multicolumn{2}{c}{$\begin{array}{c}\text { Std. } \\
\text { Error }\end{array}$} & $\begin{array}{c}\text { 95\% Confidence } \\
\text { Interval of Diff. }\end{array}$ \\
\hline Posttest & & & & & & Lower & Upper \\
\hline & $\begin{array}{l}\text { Equal var. assum. } \\
\text { Equal var. not } \\
\text { assum. }\end{array}$ & 7.932 & 62 & .000 & 10.812 & 1.363 & 8.087 & 13.537 \\
& 7.932 & 61.467 & .000 & 10.812 & 1.363 & 8.087 & 13.537 \\
\hline
\end{tabular}

Based on the results of the N-gain analysis in both classes, it was found that there was an increase in posttest results, but the increase in students' conceptual mastery in the experimental class was higher than the control class. This can be proven based on the acquisition of the $\mathrm{N}$-gain value obtained by the experimental class which is 0.85 in the high category while the control class is 0.66 in the medium category. Based on the data obtained, it is known that learning using a guided inquiry model assisted by animated video media is better than learning that does not use animated video media.

The use of animated video media makes students' attention more focused during the learning process, because the material presented by the teacher is not only verbal. In addition, presenting material through animated video media will be easier for students to understand and make students' memories stronger. So that students will more easily master the concept after the learning process by using video media (Allo, Sugiarti, \& Salempa, 2017). Waves are a fun physics material, but they become difficult for students if they are only explained with lectures, unlike when they are explained using animated videos. Students are more interested in learning and feel that the material being taught is useful so that it is easier for students to understand the concept of waves (Putri, 2012). The use of animated video media has also been proven to increase student motivation and learning outcomes. Previous study results (Devanti \& Jumrodah, 2015) obtained the results that animated video media had a significant effect on student learning outcomes compared to the learning process without animated video media. This is in line with the results in this study that the use of animated video media affects students' mastery of physics concepts, especially waves, students feel that learning by using animated videos is no longer just imagining but can understand its meaning so that the wave material becomes more fun and has an effect on increasing mastery of concepts. student physics. The use of guided inquiry model is proven to improve student learning outcomes and motivation (Kusdiastuti et al., 2017), In this study it was also found that the guided inquiry model could improve students' mastery of physics concepts specifically for wave material, and mastery of physics concepts was even better when using animated video media.

\section{CONCLUSION}

The use of animated video media in the learning process has a significant effect on students' mastery of physics concepts. The increase in students' mastery of physics concepts 
also increased with an $\mathrm{N}$-gain value of 0.85 which was included in the high category compared to student learning outcomes with the learning process without using animated videos.

\section{RECOMMENDATION}

The use of animated video media is highly recommended, especially in the physics learning process because it can improve understanding of physics concepts and for research, other media can also be developed.

\section{REFERENCES}

Allo, R. A., Sugiarti, S., \& Salempa, P. (2017). Pengaruh Penggunaan Media Animasi melalui Model Pembelajaran Inkuiri Terbimbing Terhadap Motivasi dan Hasil Belajar Siswa Kelas VII SMPN 30 Makassar (Studi pada Materi Pokok Karakteristik Zat). Chemica: Jurnal Ilmiah Kimia dan Pendidikan Kimia, 18(2), 80-89.

Budiyono, A., Hair, M. A., Wildani, A., \& Firdausiyah, F. (2020). Pengaruh Learning Cycle 5e Berbantuan Permainan Monopoli Fisika Berpoin (MOKAIN) Terhadap Penguasaan Konsep Peserta Didik SMA. Edu Sains: Jurnal Pendidikan Sains dan Matematika, 8(2), 22-31.

Devanti, D., \& Jumrodah, J. (2015). Pengaruh Media Animasi Terhadap Hasil Belajar Konsep Sistem Peredaran Darah Manusia Siswa Kelas VIII Mts Raudhatul Jannah Palangkaraya. Edu Sains: Jurnal Pendidikan Sains dan Matematika, 3(2).

Gunawan, G., Harjono, A., \& Imran, I. (2016). Pengaruh Multimedia Interaktif dan Gaya Belajar Terhadap Penguasaan Konsep Kalor Siswa. Jurnal Pendidikan Fisika Indonesia, 12(2), 118-125.

Gunawan, G., Harjono, A., \& Sutrio, S. (2017). Multimedia Interaktif dalam Pembelajaran Konsep Listrik bagi Calon Guru. Jurnal Pendidikan Fisika dan Teknologi, 1(1), 9-14.

Hafsyah, S. N., Prihandono, T., \& Yushardi, Y. (2021). Penerapan Model Inkuiri Terstruktur dengan Media Virtual-Lab Pada Pembelajaran Fisika di SMP. Jurnal Pembelajaran Fisika, 1(2), 158-164.

Hake, R. R. (1999). Analyzing change/gain scores: Indiana: Indiana University.

Indrajit, D. (2009). Mudah dan Aktif Belajar Fisika: PT Grafindo Media Pratama.

Kurniawati, I. D., \& Diantoro, M. (2014). Pengaruh pembelajaran inkuiri terbimbing integrasi peer instruction terhadap penguasaan konsep dan kemampuan berpikir kritis siswa. Jurnal Pendidikan Fisika Indonesia, 10(1).

Kusairi, S. (2013). Pengaruh blended learning terhadap penguasaan konsep dan penalaran fisika peserta didik kelas X. Jurnal Pendidikan Fisika Indonesia, 9(1).

Kusdiastuti, M., Harjono, A., Sahidu, H., \& Gunawan, G. (2017). Pengaruh Model Pembelajaran Inkuiri Berbantuan Laboratorium Virtual Terhadap Penguasaan Konsep Fisika Peserta Didik. Jurnal Pendidikan Fisika dan Teknologi, 2(3), 116-122.

Lia, L. (2018). Kemampuan Mahasiswa dalam Membuat Alat Peraga Fisika melalui Pembelajaran Berbasis Proyek. Wahana Didaktika: Jurnal Ilmu Kependidikan, 16(2), 222-234.

Putri, D. H. (2012). Model kegiatan laboratorium berbasis problem solving pada pembelajaran gelombang dan optik untuk meningkatkan keterampilan proses sains mahasiswa. EXACTA, 10(2), 148-155.

Rahim, H. F. (2020). Pengaruh pembelajaran inkuiri terbimbing berbantuan animasi terhadap penguasaan konsep suhu dan kalor siswa kelas XI SMA laboratorium UM Malang. Universitas Negeri Malang.

Umami, R., \& Jatmiko, B. (2013). Penerapan Model Pembelajaran Inkuiri dengan Pendekatan SETS (Science, Environment, Technology and Society) pada Pokok Bahasan Fluida Statis untuk Meningkatkan Keterampilan Berpikir Kritis Siswa Kelas XI SMA Negeri 1 Gedangan. Inovasi Pendidikan Fisika, 2(3). 
Wijayanti, P., \& Hindarto, N. (2010). Eksplorasi kesulitan belajar siswa pada pokok bahasan cahaya dan upaya peningkatan hasil belajar melalui pembelajaran inkuiri terbimbing. Jurnal Pendidikan Fisika Indonesia, 6(1).

Yulianci, S., Gunawan, G., \& Doyan, A. (2017). Model Inkuiri Terbimbing Berbantuan Multimedia Interaktif Untuk Meningkatkan Penguasaan Konsep Fisika Peserta Didik. Jurnal Pendidikan Fisika dan Teknologi, 3(2), 146-154. 